\title{
Electricity Generation from Hospital Wastewater in Microbial Fuel Cell using Radiation Tolerant Bacteria
}

\author{
Pimprapa Chaijak 1,2,*任, Monthon Lertworapreecha ${ }^{3}$, Nopparit Changkit ${ }^{4}$, Phachirarat Sola ${ }^{4}$ \\ Department of Biology, Faculty of Science, Thaksin University, Phatthalung 93210, Thailand \\ Microbial Fuel Cell \& Bioremediation Laboratory, Faculty of Science, Thaksin University, Phatthalung 93210, Thailand \\ Department of Microbiology, Faculty of Science, Thaksin University, Phatthalung 93210, Thailand \\ 4 Thailand Institute of Nuclear Technology (Public Organization) (TINT), Nakhon Nayok 26120, Thailand \\ * Correspondence: chaihajak.pimprapa@gmail.com (P.C.);
}

Scopus Author ID 57195740686

Received: 30.06.2021; Revised: 30.08.2021; Accepted: 5.09.2021; Published: 20.10.2021

\begin{abstract}
Hospital waste is a type of hazardous waste that contains a wide range of dangerous substances, including radioactive materials. Radiation-tolerant microbes have shown an interest in treating this liquid waste. Radiation-resistant microorganisms were chosen from irradiated fermented sausage in this investigation. The activity of enzymes such as protease, lipase, and laccase was studied. For hospital wastewater treatment, a single chamber microbial fuel cell (sMFC) with a radiation-tolerant bacterial consortium was deployed. The microbial structure analysis showed the selected consortium was similar to Acinetobacter sp. The COD was removed at a rate of $90.10 \pm 0.30 \%$, and the power density (PD) was $168.91 \pm 3.89 \mathrm{~mW} / \mathrm{m}^{2}$. This was the first study to use the radiationresistant Acinetobacter sp. bacterial consortia to treat hospital waste and generate power simultaneously.
\end{abstract}

Keywords: hospital wastewater; gamma radiation; Laccase; microbial fuel cell

(c) 2021 by the authors. This article is an open-access article distributed under the terms and conditions of the Creative Commons Attribution (CC BY) license (https://creativecommons.org/licenses/by/4.0/).

\section{Introduction}

Hospital waste is a source of high concentrations of complicated micro-contaminants for which no specialized treatment has been investigated yet. This liquid waste and its impurities endanger the unit operation of the hospital's wastewater treatment plant [1]. Hospital waste is released at a rate of 400-1,200 L/day/bed in developed countries than 200-400 L/day/bed in developing countries [2]. Drug residues, chemicals, pathogenic microbes, and poisons are all found in hospital waste [3]. DNA damage, ecotoxicity, toxic impact, and drugresistance pathogens are some of the unfavorable health effects [4-5]. Furthermore, radioactive chemicals such as technetium-99m (Tc-99m), Iodine-131 (I-131), Iodine-125 (I-125), Iodine123 (I-123), Flourine-18 (F-18), Tritium (H-3), and Carbon-14 (C-14) are found in hospital effluent, which has a severe impact on human health [6]. By producing DNA damage, radioactive waste poses a threat to living organisms. Chemical, physical, and biological treatment methods are required to manage radioactive leftovers. The radioactive residue can be degraded and converted to renewable energy, such as electricity. These methods are costeffective, viable, and environmentally friendly [7].

Bacteria that are resistant to radiation are often resistant to DNA and protein damage. They've been discovered in hot springs [8], red mud [9], cow dung [10], mining sites [11], marine sediment [12], and other places. Radiation-resistant microorganisms are commonly 
used in the bioremediation of toxic compounds. However, there was no mention of bioremediation and simultaneous power generation from hospital effluent.

A microbial fuel cell (MFC) is a bioreactor that uses electron-releasing microorganisms (exoelectrogen) to degrade contaminants and generate power from waste [13]. Pharmaceutical waste [13], high-salinity waste [14], dairy [15], household [16], and other forms of waste have all been used.

Radiation-resistant bacteria were gathered and chosen from irradiated fermented pork sausages in this study. The activities of enzymes (lipase, protease, and laccase) were studied. Finally, it was used in a single-chamber MFC to treat hospital waste while also generating power.

\section{Materials and Methods}

\subsection{Screening of gamma-radiation tolerant bacteria.}

The 50 samples of irradiated fermented pork sausages were collected from the local market in Phatthalung province, Southern Thailand. The gamma-radiation tolerant bacteria were enriched according to the modified method of Lee et al. [17]. To avoid fungal growth, $1.0 \mathrm{~g}$ of irradiated samples were suspended in $10 \mathrm{~mL}$ sterilized nutrient broth (NB, Himedia) with $50 \mathrm{mg} / \mathrm{L}$ nystatin and incubated at $30^{\circ} \mathrm{C}$ for 3 days. The $10 \%(\mathrm{v} / \mathrm{v})$ of growing bacteria was transferred to $90 \%$ (v/v) new media 5 times to ensure they could be cultured in a laboratory. The mixed cultures were grown under facultative anaerobic conditions.

\subsection{Enzyme activity.}

Hospital waste is a high chemical oxygen demand (COD) liquid waste that mainly contains biodegradable organic materials (protein and lipid) and antimicrobial agents [3, 18]. Bacteria with protease, lipase, and laccase activities were chosen to treat hospital waste.The $10 \%(\mathrm{v} / \mathrm{v})$ mixed cultures $\left(1.0 \times 10^{7}\right.$ cell $\left./ \mathrm{mL}\right)$ were inoculated into $90 \%(\mathrm{v} / \mathrm{v})$ sterilized NB and incubated at $30^{\circ} \mathrm{C}$ for 3 days. The cultured mixed cultures were centrifuged at 12,000 rpm for 5 mins at $4{ }^{\circ} \mathrm{C}$. The supernatants were collected and stored at $4{ }^{\circ} \mathrm{C}$ until they were used. The protease activity was determined by the modified method of Sharmin et al. [19]. The lipase activity was determined according to the study of Sirisha et al. [20]. The laccase activity was measured using the method described by Chaijak et al. [21].

\subsection{Bacterial community structure.}

Total genomic DNA (gDNA) of selected gamma-radiation tolerant bacteria was extracted from $1.0 \mathrm{~g}$ of $24 \mathrm{hr}$-old cell pellets using a PCR-ready genomic DNA extraction kit (Bio-Rad, Thailand). The microbial community of the wastewater sludge was carried out by using the modified method of Denaturing gradient gel electrophoresis (DGGE) analysis according to de Lillo et al. [22] and Muyzer et al. [23]. The DGGE profile of the gammaradiation tolerant bacteria was generated on an $8.0 \%$ polyacrylamide gel with 40-60\% gradient denaturant solution for $16 \mathrm{hr}$ at $70 \mathrm{~V}$ in $1 \mathrm{x}$ Tri-acetate ethylenediaminetetraacetic acid (EDTA) buffer at $60^{\circ} \mathrm{C}$. 


\subsection{Hospital wastewater treatment.}

The synthetic hospital waste was prepared according to Tiwari et al. [24] and Guerrero et al. [25]. Briefly, the working synthetic waste was freshly prepared (prepared day by day). Glucose was used as a carbon source. The yeast extract was desired protein $100 \mathrm{mg} / \mathrm{L}$, and the sunflower oil was desired lipid $13 \mathrm{mg} / \mathrm{L}$. In comparison, $50 \mathrm{mg} / \mathrm{L}$ of penicillin was used as an antimicrobial agent [26]. The final chemical oxygen demand (COD) of synthetic waste was $1,500 \mathrm{mg} / \mathrm{L}$. The $10 \%(\mathrm{v} / \mathrm{v})$ of the selected gamma-resistant consortium was inoculated into the $90 \%(\mathrm{v} / \mathrm{v})$ synthetic hospital waste and incubated at $30{ }^{\circ} \mathrm{C}$ for 3 days without shaking. The COD, lipid, protein, and penicillin removal [27] were monitored and calculated.

\subsection{Bio-electricity generation}

The single ceramic-separator microbial fuel cell (CMFC) was constructed according to the study of Chaijak et al. [28], shown in Figure 1. The $15 \mathrm{~cm}^{2}$ carbon cloth was used as an electrode. The stainless steel wire with a $10 \mathrm{~mm}$ diameter (TRUSCO, Thailand) was connected between the electrodes. The cathode and anode were separated by a $2 \mathrm{~mm}$ thick ceramic plate. To accumulate a selected culture on the electrode surface, the consortium's $10 \%(\mathrm{v} / \mathrm{v})$ was inoculated into the anode chamber. The freshly synthesized hospital waste was then poured into a $100 \mathrm{~mL}$ working volume. The CMFC system operated at $30^{\circ} \mathrm{C}$ for 3 days and fed all the liquids. After that, $100 \mathrm{~mL}$ of fresh synthetic waste was added to an anode chamber. As a control, fresh waste without a consortium was used. The open-circuit voltage (OCV) and close circuit voltage (CCV) at 1,000 $\Omega$ were determined. The current (mA), current density $\left(\mathrm{mA} / \mathrm{m}^{2}\right)$, power $(\mathrm{mW})$ and power density $\left(\mathrm{mW} / \mathrm{m}^{2}\right)$ were calculated following Eq. (1) - (4).

$$
\begin{array}{lll}
\mathrm{I} & = & \mathrm{V} / \mathrm{R} \\
\mathrm{CD} & = & \mathrm{I} / \mathrm{A} \\
\mathrm{P} & = & \mathrm{IV} \\
\mathrm{PD} & = & \mathrm{P} / \mathrm{A}
\end{array}
$$

where $\mathrm{I}$ is the current (mA), V is the CCV at $1,000 \Omega(\mathrm{mV}), \mathrm{R}$ is the external resistance $(\Omega)$, CD is the current density $\left(\mathrm{mA} / \mathrm{m}^{2}\right)$, the $\mathrm{A}$ is the electrode area $\left(\mathrm{m}^{2}\right), \mathrm{P}$ is the power $(\mathrm{mW})$, and $\mathrm{PD}$ is the power density $\left(\mathrm{mW} / \mathrm{m}^{2}\right)$.

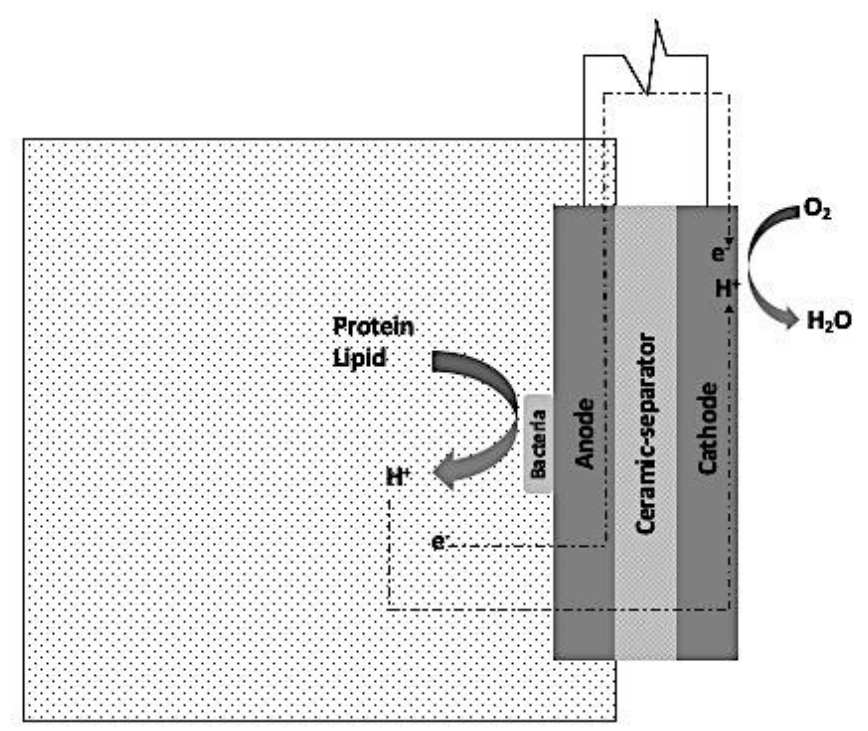

Figure 1. Schematic of CMFC used in this experiment. 


\section{Results and Discussion}

\subsection{Selection of gamma-tolerant bacteria.}

Gamma radiation is commonly employed in various applications, including material enhancement and food preservation, including sterilization [29]. The archaea and bacteria are the most well-known gamma-tolerant microorganisms. Deep-sea silt and other sediment have been reported to have gamma-radiation resistant microorganisms that can tolerate high dose radiation of 3-30 KGray [30].

In Southern Thailand, 50 irradiated sausage samples were collected aseptically. The 11 samples were obtained after 3 days of incubation in basic bacterial media treated with fungicide. They were transferred five times to ensure that they could grow in the lab without utilizing the sample as a supplement. Only four mixed cultures (GR09, GR30, GR40, and GR50) demonstrated growing ability.

\subsection{Enzyme activity.}

Proteins, lipids, and antibacterial agents make for more than $70 \%$ of the organic matter in hospital and home wastewater [26, 31]. Lipase, protease, and laccase-producing microorganisms play a significant role in treating hazardous compounds in wastewater [32]. Fermented sausage is a well-known fermented food produced by proteolytic and lipolytic bacteria such as Lactobacillus plantarum and Staphylococcus xylosus [33]. Furthermore, Kanagaraj et al. [34] discovered that lactic acid bacteria isolated from fermented sausage could generate high laccase activity with $1.128 \mathrm{U} / \mathrm{mL}$ in prior work.

In this investigation, gamma-radiation-resistant microorganisms were isolated from irradiated fermented sausage. The enzyme activities of growing bacteria were assessed after the selection process. The protease, lipase, and laccase activities were determined using $10 \%$ (v/v) of enriched mixed cultures (GR09, GR30, GR40, and GR50). Figure 2 depicts the outcome of enzyme activity. The GR09 produced the highest protease and lipase activity of $1.96 \pm 0.06$ and $1.32 \pm 0.03 \mathrm{U} / \mathrm{mL}$, respectively. The consortium which yielded the laccase activity of $1.32 \pm 0.03$ was the same.

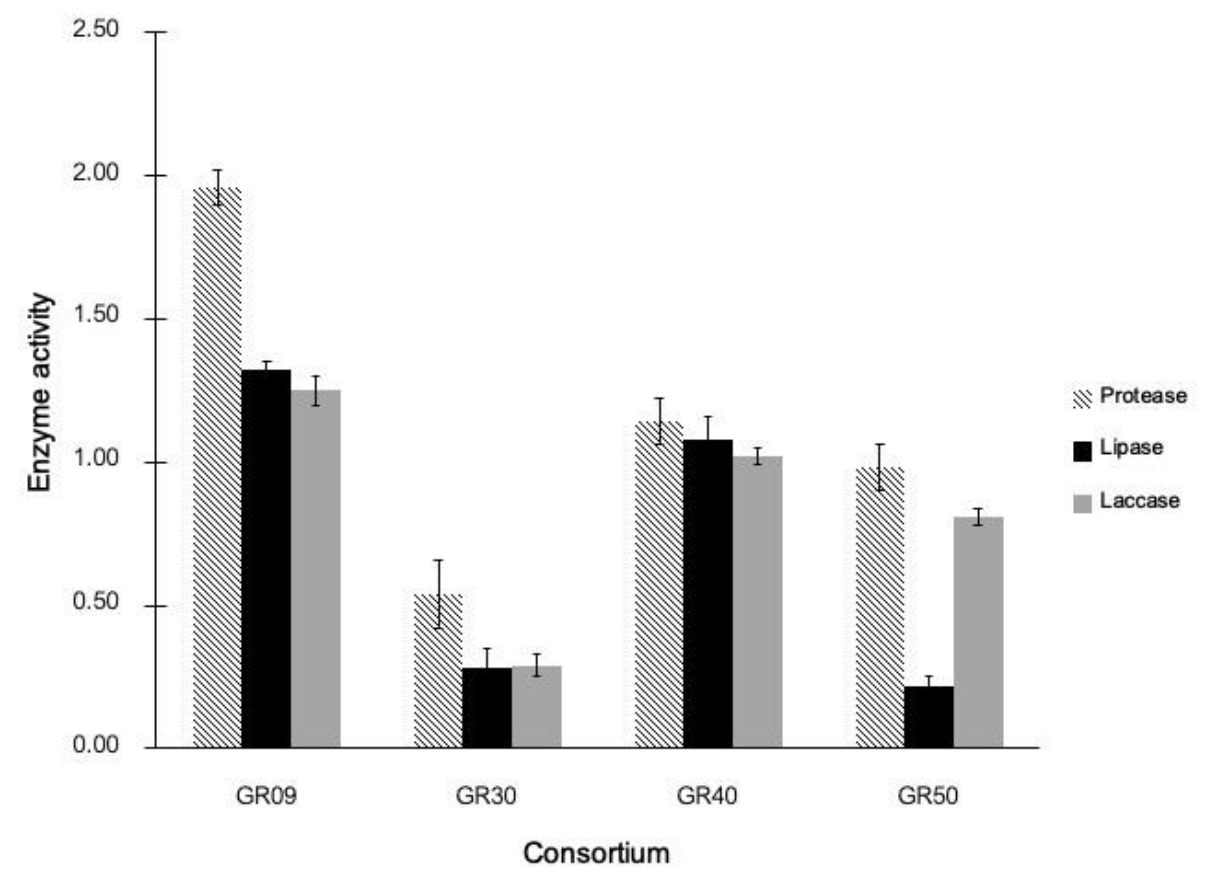

Figure 2 Enzyme activities of the gamma-tolerant bacterial consortium. 


\subsection{Bacterial community structure.}

The DGGE of a PCR amplified 16S rDNA fragment has traditionally been utilized for bacterial population fingerprinting. In the study of bacterial population structure, species identification is important [35]. Figure 3 shows the DGGE profiles of the bacterial population derived from DNA isolated directly from GR09. According to the findings, Acinetobacter sp. is the most common genus in the radiation-resistant bacterial consortia. According to a study by Xu et al., Escherichia coli isolated from irradiated chicken products can withstand gammaradiation of $0.30-0.39 \mathrm{kGy}[36]$.

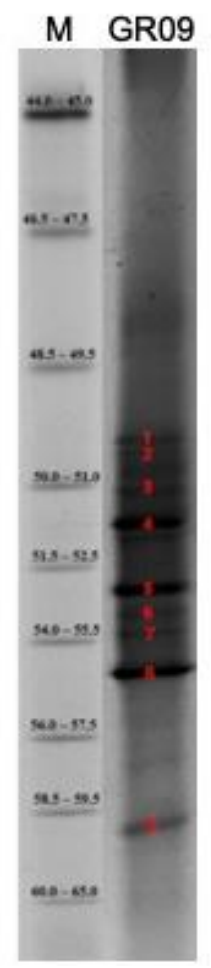

Figure 3. The DGGE profile of GR09.

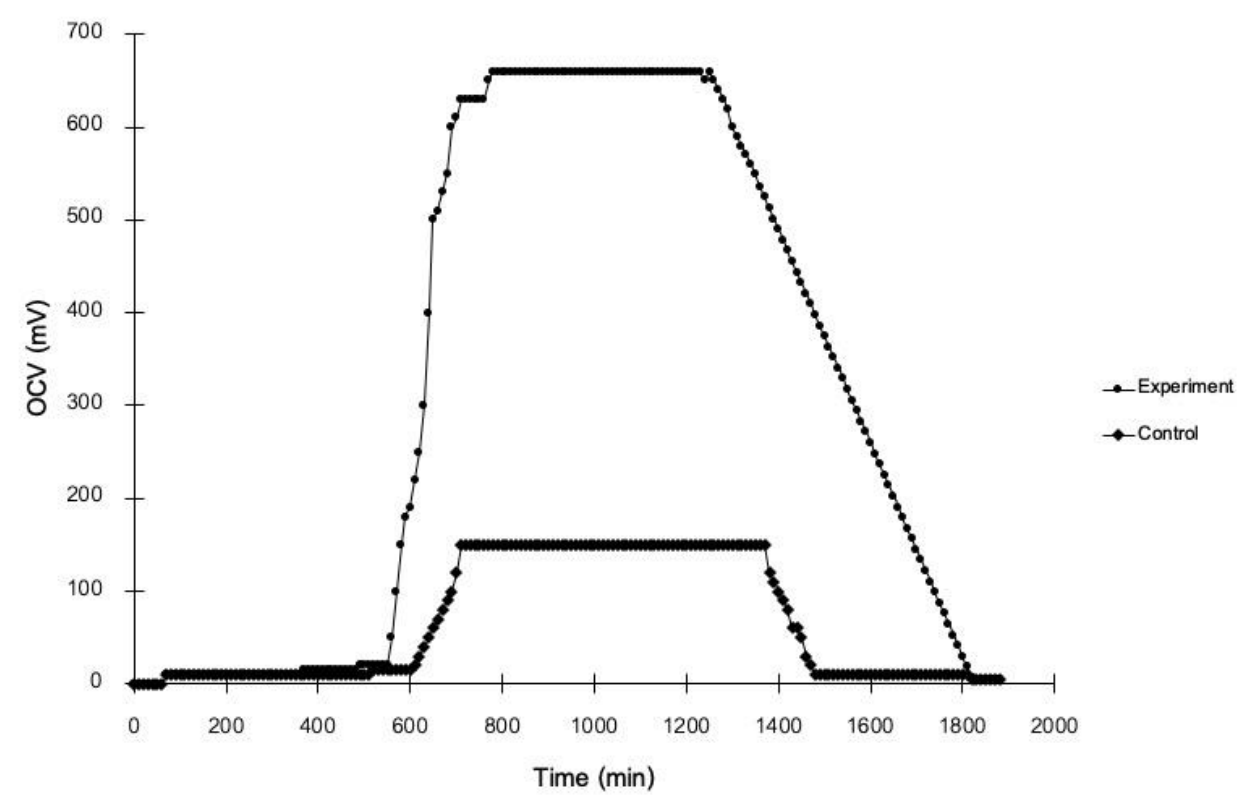

Figure 4 The OCV of sMFC in this experiment.

Table 1 The comparison of hospital wastewater treatment in this experiment with others. 
3.4. Hospital wastewater treatment \& electrochemical properties.

Due to their multi-benefits, such as power production, contaminant removal, and intrinsic low energy requirement, MFCs have recently attracted more interest in hospital wastewater treatment. They are employed as a therapeutic method for removing antibacterial agents [37].

The performance of MFCs in terms of COD elimination was evaluated in this study. The COD elimination was determined after the exoelectrogen's initial start-up acclimation time. The initial COD level was around $1,500 \mathrm{mg} / \mathrm{L}$. COD elimination was obtained at a rate of $90.10 \pm 0.30 \%$ during the stationary phase. Moreover, $80.52 \pm 2.32 \%$ of penicillin removal was gained. The comparison of hospital wastewater treatment in this experiment with others was shown in Table 1. The electrochemical properties of this experiment revealed an opencircuit voltage (OCV) of $660.00 \pm 10.00 \mathrm{mV}$ (Figure 4), a CD of $335.56 \pm 3.85 \mathrm{~mA} / \mathrm{m}^{2}$, and a PD of $168.91 \pm 3.89 \mathrm{~mW} / \mathrm{m}^{2}$, which is greater than the control rates of $77.27 \%, 92.05 \%$, and $99.34 \%$.

\begin{tabular}{l|c|c|c|c|c}
\multicolumn{1}{c|}{ Process } & $\begin{array}{c}\text { Initial COD } \\
\text { concentration } \\
(\mathbf{m g} / \mathbf{L})\end{array}$ & $\begin{array}{c}\text { Initial antibiotic } \\
\text { agent } \\
\text { concentration } \\
(\mathbf{m g} / \mathbf{L})\end{array}$ & $\begin{array}{c}\text { COD removal } \\
\mathbf{( \% )}\end{array}$ & $\begin{array}{c}\text { Power output } \\
\left(\mathbf{m W} / \mathbf{m}^{\mathbf{2}}\right)\end{array}$ & Reference \\
\hline $\begin{array}{l}\text { Single chamber MFC } \\
(\mathrm{sMFC})\end{array}$ & 1,500 & 50 & $90.10 \pm 0.30$ & $168.91 \pm 3.89$ & This study \\
\hline Dual chamber MFC & 900 & $4-128$ & 90.50 & 700 & {$[37]$} \\
\hline $\begin{array}{l}\text { Constructed wastewater } \\
\text { treatment system }\end{array}$ & 307 & NA & 57.00 & 0.00 & {$[38]$} \\
\hline $\begin{array}{l}\text { Submerged membrane } \\
\text { bioreactor (SMBR) }\end{array}$ & 2,000 & NA & 85.00 & 0.00 & {$[39]$} \\
\hline $\begin{array}{l}\text { Aerobic fluidized bed } \\
\text { Bioreactor }\end{array}$ & NA & NA & 72.00 & 0.00 & {$[40]$}
\end{tabular}

The results showed that the SMFC had a larger potential for COD removal from hospital wastewater than previous works, but it still had a lesser potential than the dual chamber MFC, as shown in Table 1. The sMFC, on the other hand, can work at a greater initial COD concentration.

\section{Conclusions}

The gamma radiation-resistant bacteria isolated from irradiated fermented pork sausage showed great potential for COD elimination in SMFC, with a maximum PD of 168.913.89 $\mathrm{mW} / \mathrm{m}^{2}$ and no energy consumption. The $\mathrm{sMFC}$ with radiation-resistant bacteria appears to be a promising approach for treating hospital wastewater while also generating power.

\section{Funding}

This research was funded by a TINT to University grant under the Thailand Institute of Nuclear Technology (Public Organization).

\section{Acknowledgments}

The authors are grateful to the Department of Biology, Faculty of Science, Thaksin University for laboratory support. 


\section{Conflicts of Interest}

The authors declare no conflict of interest.

\section{References}

1. Khan, A.H.K.; Khan, N.A.; Ahmed, S.; Dhingra, A.; Singh, C.P.; Khan, S.U.; Mohammadi, A.A.; Changani, F.; Yousefi, M.; Alam, S.; Vambol, S.; Vambol, V.; Khursheed, A.; Ali, I. Application of advanced oxidation processses followed by different treatment technologies for hospital wastewater treatment. Journal of Cleaner Production 2020, 269, 122411, https://doi.org/10.1016/j.jclepro.2020.122411.

2. Top, S.; Akgun, M.; Kipcak, E.; Bilgili, M.S. Treatment of hospital wastewater by supercritical water oxidation process. Water Research 2020, 185, 116279, https://doi.org/10.1016/j.watres.2020.116279.

3. Gholipour, S.; Nikaeen, M.; Farhadkhani, M.; Nikmanesh, B. Survey of Listeria monocytogenes contamination of various environmental samples and associated health risks. Food Control 2020, 108, 106843, https://doi.org/10.1016/j.foodcont.2019.106843.

4. Felis, E.; Kalka, J.; Sochacki, A.; Kowalska, K.; Bajkacz, S.; Harnisz, M.; Korzeniewska, M. Antimicrobial pharmaceuticals in the aquatic environment - Occurrence and environmental implications. European Journal of Pharmacology 2020, 866, 172813, https://doi.org/10.1016/j.ejphar.2019.172813.

5. Mubedi, J.I.; Devarajan, N.; Faucheur, S.L.; Mputu, J.K.; Atibu, E.K.; Sivalingam, P.; Prabakar, K.; Mpiana, P.T.; Wildi, W.; Pote, J. Effects of untreated hospital effluents on the accumulation of toxic metal in sediments of receiving system under tropical conditions: case of south India and democratic republic of Congo. Chemosphere 2013, 93, 1070-1076, https://doi.org/10.1016/j.chemosphere.2013.05.080.

6. Khan, S.; Syed, A.T.; Ahmad, R.; Rather, T.A.; Ajaz, M.; Jan, F.A. Radioactive waste management in a hospital. International Journal of Health Science 2010, 4, 39-46.

7. Natarajan, V.; Karunanidhi, M.; Raja, B. A critical review on radioactive waste management through biological techniques. Environmental Science and Pollution Research 2020, 27, 29812-29823, https://doi.org/10.1007/s11356-020-08404-0.

8. Enyedi, N.T.; Anda, D.; Borsodi, A.K.; Szabo, A.; Pal, S.E.; Ovari, M.; Marialigeti, K.; Kovacs-Bodor, P.K.; Madl-Szonyi, J.; Makk, J. Radioactive environment adapted bacterial communities constituting the biofilm of hydrothermal spring caves (Budapest, Hungary). Journal of Environmental Radioactivity 2019, 203, 8-17, https://doi.org/10.1016/j.jenvrad.2019.02.010.

9. Qu, Y.; Li, H.; Wang, X.; Tian, W.; Shi, B.; Yao, M.; Zhang, Y. Bioleaching of major, rare earth, and radioactive elements from red mud by using indigenous chemoheterotrophic bacterium Acetobacter sp. Minerals 2019, 9, 67, https://doi.org/10.3390/min9020067.

10. Saito, K.; Kuroda, K.; Suzuki, R.; Kino, Y.; Sekine, T.; Shinoda, H.; Yamashiro, H.; Fukuda, T.; Kobayashi, J.; Abe, Y.; Nishimura, J.; Urushihara, Y.; Yoneyama, H.; Fukumoto, M.; Isogai, E. Intestinal bacteria as powerful trapping lifeforms for the elimination of radioactive cesium. Frontiers in Veterinary Science 2019, 6, 70, https://doi.org/10.3389/fvets.2019.00070.

11. Sowmya, S.; Rekha, P.D.; Yashodhara, I.; Karunakara, N.; Arun, A.B. Uranium tolerant phosphate solubilizing bacteria isolated from Gogi, a proposed uranium mining site in South India. Applied Geochemistry 2020, 114, 104523, https://doi.org/10.1016/j.apgeochem.2020.104523.

12. Manobala, T.; Shukla, S.K.; Rao, T.S.; Kumar, M.D. Uranium sequestration by biofilm-forming bacteria isolated from marine sediment collected from Southern coastal region of India. International Biodeterioration \& Biodegradation 2019, 145, 104809, https://doi.org/10.1016/j.ibiod.2019.104809.

13. Rashid, T.; Sher, F.; Hazafa, A.; Hashmi, R.Q.; Zafar, A.; Rasheed, T.; Hussain, S. Design and feasibility study of novel paraboloid graphite based microbial fuel cell for bioelectrogenesis and pharmaceutical wastewater treatment. Journal of Environmental Chemical Engineering 2021, 9, 104502, https://doi.org/10.1016/j.jece.2020.104502.

14. Zhang, L.; Wang, J.; Fu, G.; Zhang, Z. Simultaneous electricity generation and nitrogen and carbon removal in single chamber microbial fuel cell for high-salinity wastewater treatment. Journal of Cleaner Production 2020, 276, 123203, https://doi.org/10.1016/j.jclepro.2020.123203.

15. Choudhury, P.; Ray, R.N.; Bandyopadhyay, T.K.; Basak, B.; Muthuraj, M.; Bhunia, B. Process engineering for stable power recovery from dairy wastewater using microbial fuel cell. International Journal of Hydrogen Energy 2021, 46, 3171-3182, https://doi.org/10.1016/j.ijhydene.2020.06.152. 
16. Mohamed, S.N.; Hiraman, P.A.; Muthukumar, K.; Jayabalan, T. Bioelectricity production from kitchen wastewater using microbial fuel cell with photosynthetic algal cathode. Bioresource Technology 2020, 295, 122226, https://doi.org/10.1016/j.biortech.2019.122226.

17. Lee, J.J.; Srinivasan, S.; Lim, S.; Joe, M.; Lee, S.H.; Kwon, S.A.; Kwon, Y.J.; Lee, J.; Choi, J.J.; Lee, H.M.; Auh, Y.K.; Kim, M.K. Hymenobacter swuensis sp. nov.; gamma-radiation-resistant bacteria isolated from mountain soil. Current Microbiology 2014, 68, 305-310, http://doi.org/10.1007/s00284-013-0478-3.

18. Prayitno, Kusuma, Z.; Yanuwiadi, B.; Laksmono, R.W. Study of hospital wastewater characteristic in Malang city. International Journal of Engineering and Science 2013, 2, 13-16.

19. Sharmin, S.; Hossain, T.; Anwar, MN. Isolation and characterization of a protease producing bacteria Bacillus amovivorus and optimization of some factors of culture conditions for protease production. Journal of Biological Science 2005, 5, 358-362.

20. Sirisha, E.; Rajasekar, N.; Narasu, M.L. Isolation and optimization of lipase producing bacteria from oil contaminate soils. International Journal of Advanced Biological and Biomedical 2010, 4, 249-252.

21. Chaijak, P.; Sato, C.; Paucar, N.; Sukkasem, C.; Lertworapreecha, M. Decolorization and simultaneous electricity generation from aquatic pharmaceutical malachite green using Shiitake mushroom. Sydowia 2019, 71, 11-15.

22. De Lillo, A.; Ashley, F.P.; Palmer, R.M.; Munson, M.A.; Kyriacou, L.; Weightman, A.J.; Wade, W.G. Novel subgingival bacterial phylotypes detected using multiple universal polymerase chain reaction primer sets. Oral Microbiology and Immunology 2006, 21, 61-68, http://doi.org/10.1111/j.1399-302X.2005.00255.x.

23. Muyer, G.; Dewaal, E.C.; Uitterlinden, A.G. Profiling of complex microbial populations by denaturing gradient gel electrophoresis analysis of polymerase chain reaction-amplified genes coding for 16S ribosomal RNA. Applied and Environmental Microbiology 1993, 59, 695-700.

24. Tiwari, B.; Sellamuthu, B.; Piche-Choquette, S.; Drogui, P.; Tyagi, R.D.; Vaudreuil, M.A.; Sauve, S.; Buelna, G.; Dube, R. The bacterial community structure of submerged membrane bioreactor treating synthetic hospital wastewater. $\quad$ Bioresource Technology $\quad 2019, \quad 286, \quad 121362$, http://doi.org/10.1016/j.biortech.2019.121362.

25. Guerrero, L.; Montalvo, S.; Coronado, E.; Chamy, R.; Poirrier, P.; Crutchik, D.; Sanchez, E.; De La Rubia, M.A.; Borja, R. Performance evaluation of a two-phase anaerobic digestion process of synthetic domestic wastewater at ambient temperature. Journal of Environmental Science and Health, Part A 2009, 44, 673-681, http://doi.org/10.1080/10934520902847794.

26. Bagchi, S.; Behera, M. Evaluating the effect of the antibiotic ampicillin on performance of a low-cost microbial fuel cell. Journal of Hazardous, Toxic, and Radioactive Waste 2020, 24, 04020011, http://doi.org/10.1061/(ASCE)HZ.2153-5515.0000516.

27. Norzaee, S.; Bazrafshan, E.; Djahed, B.; Mostafapour, F.K.; Khaksefidi, R. UV activation of persulfate for removal of penicillin $\mathrm{G}$ antibiotics in aqueous solution. The Scientific World journal 2017, 2017, 5419487, https://doi.org/10.1155/2017/3519487 .

28. Chaijak, P.; Sato, C.; Lertworapreecha, M.; Sukkasem, C.; Boonsawang, P.; Paucar, N. Potential of biochar in a ceramic-separator microbial fuel cell (CMFC) with a laccase-based air cathode. Polish Journal of Environmental Studies 2020, 29, 499-503, http://doi.org/10.15244/pjoes/99099.

29. Gebremikael, M.T.; De Waele, J.; Buchan, D.; Soboksa, G.E.; De Neve, S. The effect of varying gamma irradiation doses and soil moisture content on nematodes, the microbial communities and mineral nitrogen. Applied Soil Ecology 2015, 92, 1-13, https://doi.org/10.1016/j.apsoil.2015.03.003

30. Jolivet, E.; L'Haridon, S.; Corre, E.; Forterre, P.; Prieur, D. Thermococcus gammatolerans sp. nov.; a hyperthermophilic archaeon from a deep-sea hydrothermal vent that resist ionizing radiation. International Journal of Systematic and Evolutionary 2003, 53, 847-851, https://doi.org/10.1099/ijs.0.02503-0.

31. Raunkjaer, K.; Hvitved-Jacobsen, T.; Neilsen, P.H. Measurement of pools of protein, carbohydrate and lipid in domestic wastewater. Water Resource 1994, 8, 251-262. https://doi.org/10.1016/0043-1354(94)90261-5

32. Gessesse, A.; Dueholm, T.; Petersen, S.B.; Nielsen, P.H. Lipase and protease extraction from activated sludge. Water Research 2003, 37, 3652-3557, https://doi.org/10.1016/S0043-1354(03)00241-0.

33. Essid, I.; Hassouna, M. Effect of inoculation of selected Staphylococcus xylosus and Lactobacillus plantarum strains on biochemical, microbiological and textural characteristics of a Tunisian dry fermented sausage. Food Control 2013, 32, 707-714, https://doi.org/10.1016/j.foodcont.2013.02.003.

34. Kanagaraj, C.; Muthuvel, P.; Ayyappadas, M.P. Screening of bacteriocin productions and associated enzyme activity from Lactobacillus acidophilus. International Journal of Biotechnology and Bioengineering Research 2015, 6, 13-18. 
35. Fontana, C.; Vignolo, G.; Cocconclli, P.S. PCR-DGGE analysis for the identification of microbial population from Argentinean dry fermented sausages. Journal of Microbiological Methods 2005, 63, 254-263, https://doi.org/10.1016/j.mimet.2005.03.010.

36. Xu, A.; Scullen, O.J.; Sheen, S.; Johnson, J.R.; Sommers, C.H. Inactivation of extraintestinal pathogenic E. coli clinical and food isolates suspended in ground chicken meat by gamma radiation. Food Microbiology 2019, 84, 1-4, https://doi.org/10.1016/j.fm.2019.103264.

37. Ondon, B.S.; Li, S.; Zhou, Q.; Li, F. Simultaneous removal and high tolerance of norfloxacin with electricity generation in microbial fuel cell and its antibiotic resistance genes quantification. Bioresource Technology 2020, 304, 122984, https://doi.org/10.1016/j.biortech.2020.122984.

38. Petrovich, M.L.; Zilberman, A.; Kaplan, A.; Eliraz, G.R.; Wang, Y.; Langenfeld, K.; Duhaime, M.; Wigginton, K.; Poretsky, R.; Avisar, D.; Wells, G.F. Microbial and viral communities and their antibiotic resistance genes throughout a hospital wastewater treatment system. Frontiers in Microbiology 2020, 11, 153, https://doi.org/10.3389/fmicb.2020.00153.

39. Morabet, R.E.; Khan, R.A.; Mallick, J.; Khan, N.A.; Ahmed, S.; Dhingra, A.; Khan, A.R.; Alsubih, M.; Alqadhi, S.; Bindajam, A. Comparative study of submerged membrane bioreactor and extended aeration process coupled with tubesettler for hospital wastewater treatment. Alexandria Engineering Journal 2020, 59, 4633-4641, https://doi.org/10.1016/j.aej.2020.08.021.

40. Alsubih, M.; Morabet, R.E.; Khan, R.A.; Khan, N.A.; Khan, A.R.; Sharma, G. Performance evaluation of aerobic fluidized bed bioreactor coupled wastewater treatment. Journal of Environmental Chemical Engineering 2021, 19, 105896, https://doi.org/10.1016/j.jece.2021.105896. 